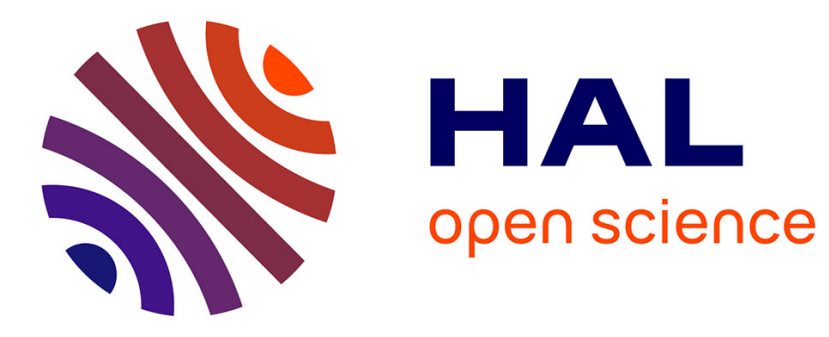

\title{
Hybrid Materials from Poly(vinyl chloride) and Organogels
}

Zakaria Zoukal, Said Elhasri, Alain Carvalho, Marc Schmutz, Dominique

Collin, Praveen Vakayil, Ayyappanpillai Ajayaghosh, Jean-Michel Guenet

\section{- To cite this version:}

Zakaria Zoukal, Said Elhasri, Alain Carvalho, Marc Schmutz, Dominique Collin, et al.. Hybrid Materials from Poly(vinyl chloride) and Organogels. ACS Applied Polymer Materials, 2019, 1 (5), pp.12031208. 10.1021/acsapm.9b00207 . hal-02401499

\section{HAL Id: hal-02401499 \\ https://hal.science/hal-02401499}

Submitted on 2 Dec 2020

HAL is a multi-disciplinary open access archive for the deposit and dissemination of scientific research documents, whether they are published or not. The documents may come from teaching and research institutions in France or abroad, or from public or private research centers.
L'archive ouverte pluridisciplinaire $\mathbf{H A L}$, est destinée au dépôt et à la diffusion de documents scientifiques de niveau recherche, publiés ou non, émanant des établissements d'enseignement et de recherche français ou étrangers, des laboratoires publics ou privés. 


\title{
HYBRID MATERIALS FROM POLY[VINYL CHLORIDE] AND
}

\section{ORGANOGELS}

\author{
Zakaria ZOUKAL ${ }^{1,2}$, Said ELHASRI ${ }^{2}$, Alain CARVALHO ${ }^{1}$, Marc SCHMUTZ ${ }^{1}$, Dominique \\ COLLIN $^{1}$, Praveen K. VAKAYIL ${ }^{3}$, Ayyappanpillai AJAYAGHOSH ${ }^{3}$, Jean-Michel GUENET ${ }^{1 *}$$$
1=\text { Institut Charles Sadron }
$$$$
\text { CNRS-Université de Strasbourg }
$$$$
23 \text { rue du Loess, BP84047 }
$$$$
67034 \text { STRASBOURG, Cedex2, FRANCE }
$$$$
\text { 2= Université Cadi Ayyad }
$$$$
\text { Faculté des Sciences et Techniques }
$$$$
\text { B.P.549 Av. Abdelkrim Al Khattabi }
$$$$
\text { Guéliz MARRAKECH 60000, MORROCO }
$$ \\ 3 $=$ Photosciences and Photonics Section, Chemical Sciences and Technology Division \\ CSIR-National Institute for Interdisciplinary Science and Technology (CSIR-NIIST), \\ THIRUVANANTHAPURAM 695019, INDIA
}

Keywords: PVC, organogels, gelation, hybrid materials, rheology, morphology 

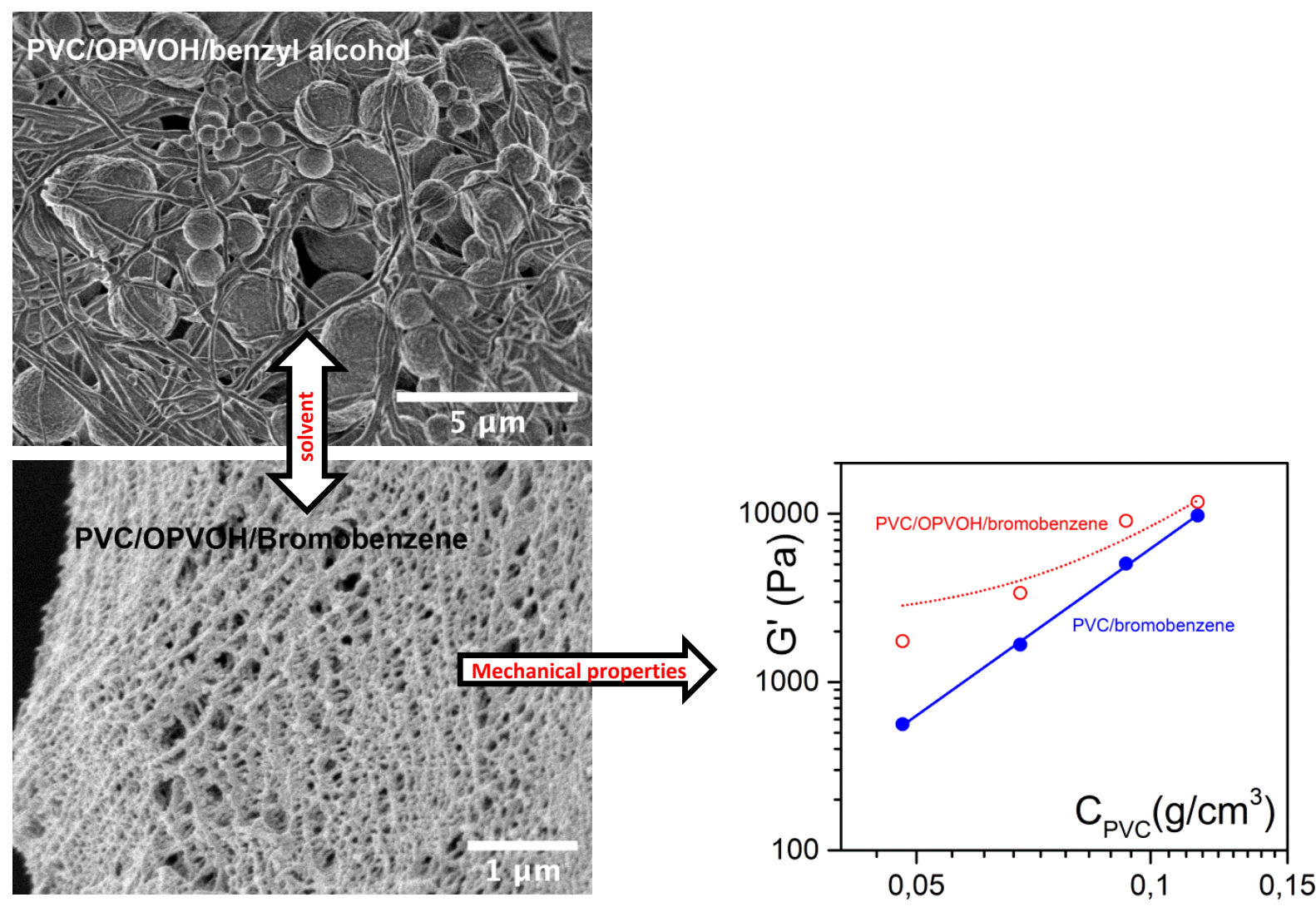

Hybrid materials from PVC and organogelators

Zakaria Zoukal, Said Elhasri, Marc Schmutz, Alain Carvalho, Dominique Collin, Vakayil K. Praveen, Ayyapanpillai Ajayaghosh, Jean-Michel Guenet

for Table of Contents use only

\begin{abstract}
The making of hybrid materials from polymers and self-assembled systems may open up new horizon for imparting new properties to usual polymers without recourse to chemistry. Here it is again shown that preparation of such materials can be straightforwardly achieved by a physical SOL-GEL process with polyvinyl chloride (PVC), an extensively-used polymer, and oligo $(p-$ phenylenevinylene) organogelators $(\mathrm{OPVOH})$, a molecule that forms organogels displaying optoelectronic properties (change of colour at the SOL-GEL transition). Low amounts of OPV with respect to PVC are used (ratio $\sim 1 / 10$ to $\sim 1 / 30$ ). Although the PVC structures form first, the thermodynamic of the OPVOH gelation is virtually not altered (same formation temperatures and same melting temperatures). It is observed that the organogel does pervade the polymer structures, which results in a noticeable strengthening of the mechanical properties. Thanks to the OPVOH opto-electronic properties, one may prepare, after appropriate solvent extraction, hybrid, porous material that may be used as a sensor for detecting in air or in water undesired molecules by alteration of the OPVOH scaffold.
\end{abstract}




\section{INTRODUCTION}

Polyvinyl chloride, PVC, the third-most widely produced synthetic polymer, is currently experiencing a renewal with respect to environmental issues thanks to its recycling to a very large extent (see http://www.vinylplus.eu/resources/publications/progress-report). The continuous interest toward this polymer arises from two essential and unique properties, triboelectricity and flameretardant $^{1}$. Although used for decades as one of the oldest synthesized polymer, PVC has still a future ahead before being superseded by polymers of equivalent properties produced by bioengineering. Attempting to impart new properties to this polymer remains a topic of interest.

PVC is basically an atactic polymer, which surprisingly produce thermoreversible gels of fibrillar morphology in a large variety of solvents ${ }^{2-4}$. This has been shown to arise from a low amount of long syndiotactic sequences that can crystallize $\mathrm{e}^{5,6}$. Because of the relatively small size of the chlorine atom, isolated iso or hetero defects along syndiotactic sequences do not hinder them from forming crystalline structures. PVC is at variance with other polymers such as polystyrene where the bulky phenyl group definitely impedes these defect-containing sequences to be accommodated into the crystal phase. Guenet and coworkers have further shown that the other types of sequences can form polymer-solvent complexes whose occurrence can account for the increase of the elastic modulus with gel aging ${ }^{7-10}$. From its wet gels, fibrils are processed for the textile industry. The gel state also affords preparation of porous materials by proper removal of the solvent ${ }^{11}$.

In a quite different domain of science, a wealth of self-assembling systems has been synthesized these past twenty years. In many cases the solutions of these molecules generate through a quench at low temperature fibrillar networks that are commonly designated as organogels or molecular gels 12-18. Interestingly, these systems often bear a functional property (opto-electronic, magnetic,..).

The merging of these two separate domains of science can offer an original approach for preparing hybrid materials that involve a polymer and a self-assembling system, thus bringing unexpected functional properties to common polymers. Recent functional materials have been prepared in this 
way 19-24. Magnetic nanomaterials have been obtained by encapsulation of ferromagnetic filaments ${ }^{20,21}$ within polymer fibrils. Insulated nanowires from encapsulated poly(3-butylthiophene2,5-diyl) (P3BT) fibrils by self-assembled nanotubes have been prepared in the same way 22 .

In this paper we report on preliminary investigations aiming at extending the design of hybrid functional materials prepared from polymers and organogels to PVC which offers more potential for apllications. The organogelator used in this preliminary study is of the type oligo( $p$ phenylenevinylene) molecule ${ }^{15,25}$, OPVOH (figure 1) whose organogels are well documented ${ }^{15,19}$. As will be again shown the making process is simple, easy to implement, while no chemistry is required. Two solvents have been considered: benzyl alcohol (BA), a poor solvent to PVC, and bromobenzene, (BB), a good solvent to PVC. While OPVOH produces fibrillar organogels in both solvents, PVC exhibits differing morphologies. In this study the OPVOH concentration has been kept constant while the PVC content has been varied.

An interesting outcome of this study deals with the significant improvement of the gel mechanical properties in spite of the low amount of organogelator.

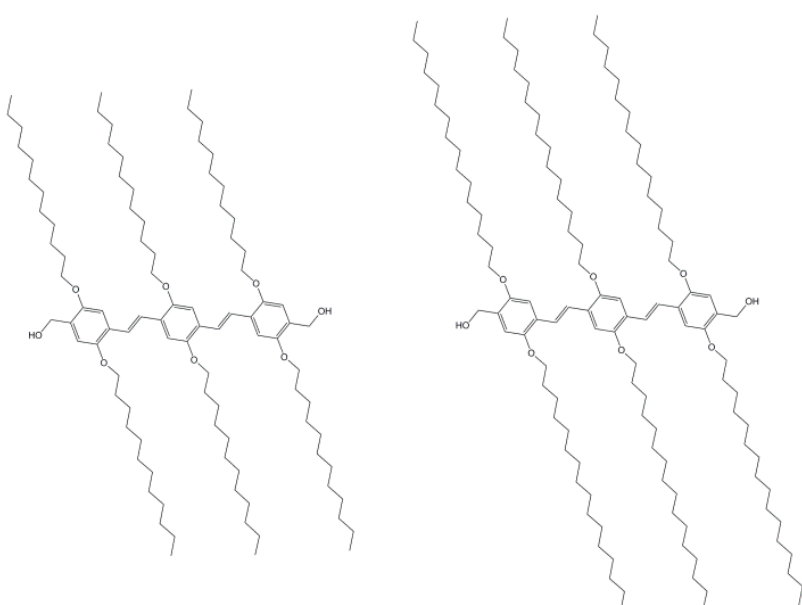

Figure 1: Chemical structure of OPVOH12 (left) and OPVOH16 (right) ${ }^{24}$.

\section{EXPERIMENTAL SECTION}

\section{Materials}

The PVC used in the present study was supplied by Rhovyl SA. The weight average molecular 
weight as determined by SEC in THF at $25^{\circ} \mathrm{C}$ (universal calibration) is $\mathrm{M}_{\mathrm{w}}=1.2 \times 10^{5} \mathrm{~g} / \mathrm{mol}$ and the polydispersity index $M_{w} / M_{n}=2.3$. The fractions of triads were obtained by ${ }^{13}$ C-NMR: syndio: $33 \%$, iso: $18 \%$, hetero: $49 \%$.

The fibrillar organogels are prepared from oligo(p-phenylenevinylene) with differing aliphatic side chains $\left(\mathrm{R}_{12}=\mathrm{C}_{12} \mathrm{H}_{25}\right.$ and $\left.\mathrm{R}_{16}=\mathrm{C}_{16} \mathrm{H}_{33}\right)$ possessing two $\mathrm{OH}$ terminal groups (designated as OPVOH12 and OPVOH16 in what follows). The synthesis and properties of these molecules are extensively described in reference 24 .

Bromobenzene (purity grade 99.5\%) and benzyl alcohol (purity grade 99\%) were purchased from SigmaAldrich and used as-received.

The preparation of the hybrid systems is quite straightforward: a mixture of PVC, organogelator and solvent is prepared at the desired concentration. Depending upon the PVC concentration and on the solvent, the system is heated up to $120-140^{\circ} \mathrm{C}$ in bromobenzene and $160-180^{\circ} \mathrm{C}$ in benzyl alcohol until a clear, homogeneous solution is obtained. Finally, the solution is quenched to low temperature $\left(0^{\circ} \mathrm{C}\right.$ down to $\left.-20^{\circ} \mathrm{C}\right)$ for producing the sample.

The PVC concentrations are ranging from $4.8 \times 10^{-2} \mathrm{~g} / \mathrm{cm}^{3}$ to $17.5 \times 10^{-2} \mathrm{~g} / \mathrm{cm}^{3}$, while the OPVOH concentration is always kept constant at $0.4 \times 10^{-2} \mathrm{~g} / \mathrm{cm}^{3}$ (see SI Table S1).

\section{Differential Scanning Calorimetry}

The gel formation and melting were investigated by means of the DSC 8500 from Perkin Elmer. Three heating and cooling rates were used, namely $5^{\circ} \mathrm{C} / \mathrm{min}, 10^{\circ} \mathrm{C} / \mathrm{min}$ and $15^{\circ} \mathrm{C} / \mathrm{min}$. The temperature range was from $-20^{\circ} \mathrm{C}$ to $150^{\circ} \mathrm{C}$. The formation and melting temperatures were determined after extrapolation to $0^{\circ} \mathrm{C} / \mathrm{min}$. The associated enthalpies were determined from the spectra obtained at $10^{\circ} \mathrm{C} / \mathrm{min}$.

Samples were prepared as described above. About $30 \mathrm{mg}$ of the mixture were then transferred to stainless steel pans that were hermetically sealed by means of an o-ring. The weight of the sample was checked after completion of the different cycles in order to evaluate any solvent loss. 


\section{Turbidity determination}

Turbidity in the samples prepared from benzyl alcohol was determined by means of an optical setup that allows measurement of the light intensity transmitted through the sample when temperature is decreased. Basically, a collimated and attenuated monochromatic beam $(\lambda=632.8 \mathrm{~nm})$ from a HeNe laser (Melles Griot 05-LHP-151) was shined onto a $5 \mathrm{~mm}$-thick cuvette containing the sample, while the transmitted light was collected onto a CCD camera (Retiga 2000R). The samples were heated at $150^{\circ} \mathrm{C}$, and then cooled at room temperature at a rate of about $1.4-1.5^{\circ} \mathrm{C} / \mathrm{min}$.

\section{Scanning Electron Microscopy}

The system PVC/BB has been observed by cryo-SEM technique. A piece of the gel was placed on a cryo-holder and quickly plunged into a nitrogen slush in the cryo preparation chamber of a Quorum PT 3010 machine. Subsequently, the sample is transferred under vacuum into the chamber attached to the microscope. There, the frozen sample is coated with a thin Pt layer (by sputter deposition) and fractured with a razor blade. A slight etching at $-100^{\circ} \mathrm{C}$ is performed to render the morphology more visible. The sample is eventually transferred in the FEG-cryoSEM (Hitachi SU8010) and observed at $1 \mathrm{keV}$ at $-150^{\circ} \mathrm{C}$. The images were taken with the SE-in lens detector. The system PVC/BA has been observed at room temperature after subsequent drying under vacuum by conventional scanning electron microscopy (Hitachi SU8010) at $1 \mathrm{keV}$.

\section{Rheology}

The real and imaginary parts of the complex shear modulus were measured with a stress-controlled rheometer (Haake, Mars III) operating in the oscillatory mode. Two types of measurements cells were chosen: plate-plate type (35 or $60 \mathrm{~mm}$ diameter) was used for measuring the elastic modulus G' as a function frequency and of PVC concentration, whereas determination of the gelation temperature in bromobenzene at constant frequency was achieved by means of a double Couette cell (DG41, Haake). The temperature in the Couette cell was regulated by an external bath (Haake F3) and that in the plate--plate cells by Peltier elements embedded in one of the plates. For all shear 
measurements the applied stresses were lower than $5 \times 10^{-2} \mathrm{~Pa}$ to ensure that the measurements were carried out in the linear response regime. The gap in the Couette cell was $\sim 400 \mu \mathrm{m}$ and the thickness of the samples was ranging between 400 and $800 \mu \mathrm{m}$ in the plate-plate set-up.

\section{RESULTS AND DISCUSSION}

Mapping out a temperature-concentration phase diagram for PVC systems turns out to be impossible from differential scanning calorimetry (DSC) investigations. The low amount of syndiotactic sequences together with their large length distribution results in the spreading of the exotherms and endotherms over a large range of temperature. Although several papers had reported observations of melting endotherms these were chiefly artefactual. Geil and coworkers have shown that the DSC endotherm systematically disappears on the second heating ${ }^{26}$. This received further support by Mutin and Guenet who showed that the artefactual enthalpy arose from a mechanical effect ${ }^{7}$.

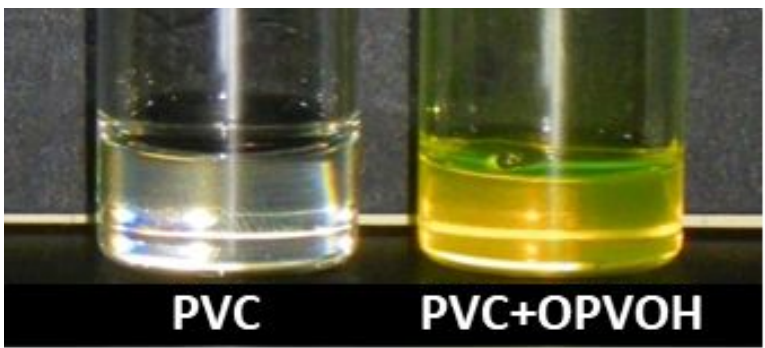

Bromobenzene

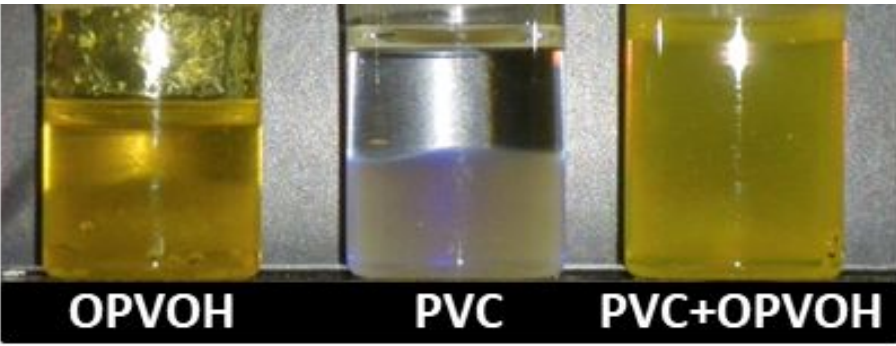

Benzyl alcohol

Figure 2: Visual aspect) at room temperature of the gels in bromobenzene (left) and the systems in benzyl alcohol (right (gel for OPVOH, phase separated system for PVC, and gel for the hybrid system). While solvent release occurs in PVC/benzyl alcohol, thus forming two macroscopic phases, it no longer occurs in PVC/OPVOH/benzyl alcohol. In all cases $\mathrm{C}_{\mathrm{PVC}}=4.8 \times 10^{-2} \mathrm{~g} / \mathrm{cm}^{3}$, $\mathrm{C}_{\mathrm{OPVOH}}=4 \times 10^{-3} \mathrm{~g} / \mathrm{cm}^{3}$.

In the aim of overcoming this drawback, the onset of "structures" formation of PVC was determined by turbidimetry observation for the PVC/benzyl alcohol system (SI figure S1, 
turbidimetry vs temperature) and rheology experiments for the $\mathrm{PVC} /$ bromobenzene gels (SI figure S2, G' and G" vs temperature). As will be apparent in what follows, rheology is not appropriate for the systems in benzyl alcohol. Conversely, turbidity measurement are not appropriate for the $\mathrm{PVC} /$ bromobenzene gels as the refractive indices are virtually identical $\left(\mathrm{n}_{\mathrm{D}}=1.565\right.$ for bromobenzene, and $\mathrm{n}_{\mathrm{D}}=1.55$ for $\left.\mathrm{PVC}\right)$.

Conversely, the formation and melting of OPVOH organogels can be detected by DSC experiments as their associated enthalpies are large enough.

\section{Gels in bromobenzene}

A transparent gel is produced with the system $\boldsymbol{P V C} \boldsymbol{C B B}$ which does not undergo any noticeable syneresis ${ }^{7}$ as shown in figure 2 . As aforementioned, transparency arises from the nearly identical refractive indices.
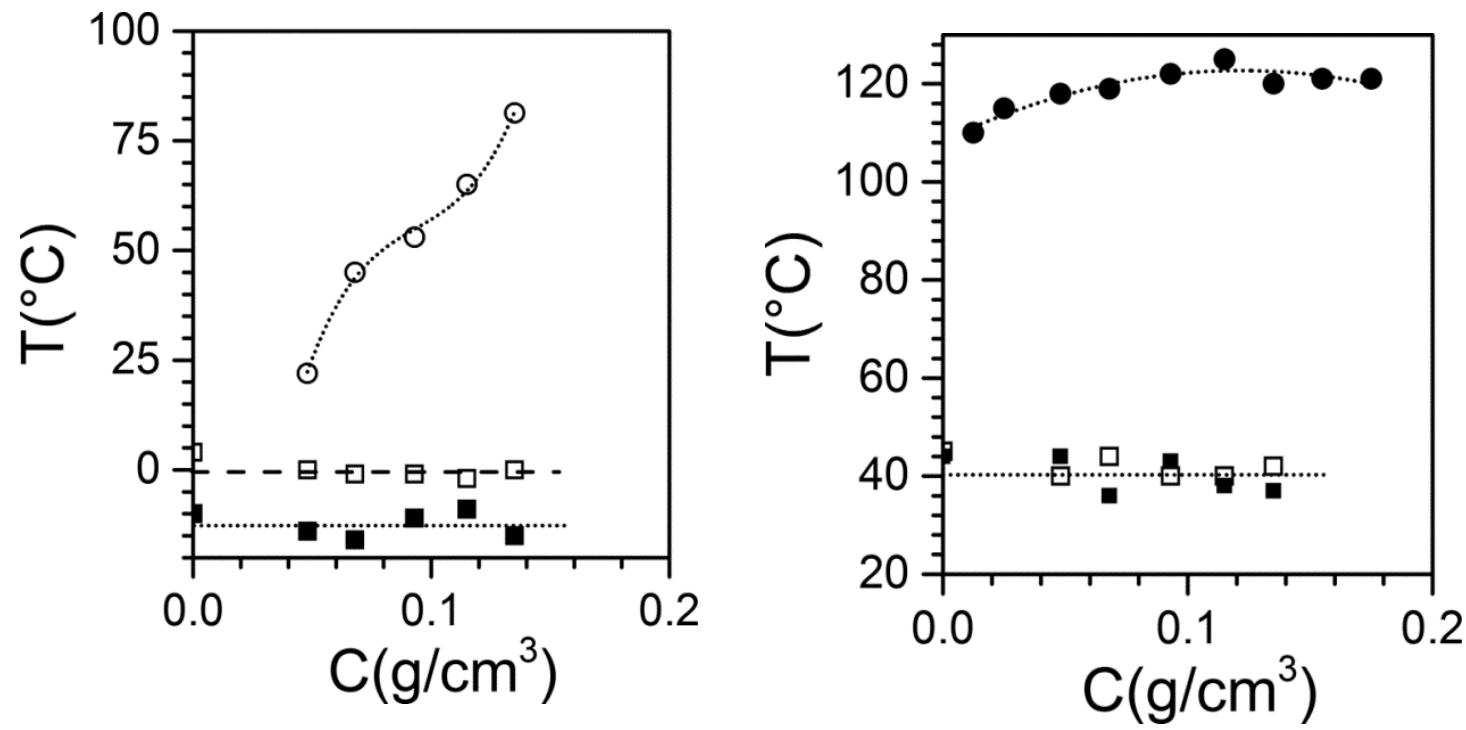

Figure 3: Structures formation temperatures vs concentration in bromobenzene (left), and in benzyl alcohol (right), (O) PVC/bromobenzene as determined by rheology, (•) PVC/benzyl alcohol as determined by turbidimetry, ( $\square$ ) OPVOH12 and (ם) OPVOH16 in the ternary systems as determined by DSC.

The gel formation temperature displayed in figure 3 left as a function of PVC concentration has been determined by oscillatory rheological experiments and taken at $G^{\prime}=G^{\prime \prime}$ (see SI figure $S 2$, G' 
and G” vs temperature).

PVC/BB morphology consists of a fibrillar network resembling a knitwear structure with a mesh size in the range $80-100 \mathrm{~nm}$ (figure 4a). This morphology confirms former observations by Yang and Geil. ${ }^{25}$. OPVOHs molecules form gels in bromobenzene that consist of an assembly of more or less straight fibrils (figure 4b) of cross-sections in the range 80-100 $\mathrm{nm}$.
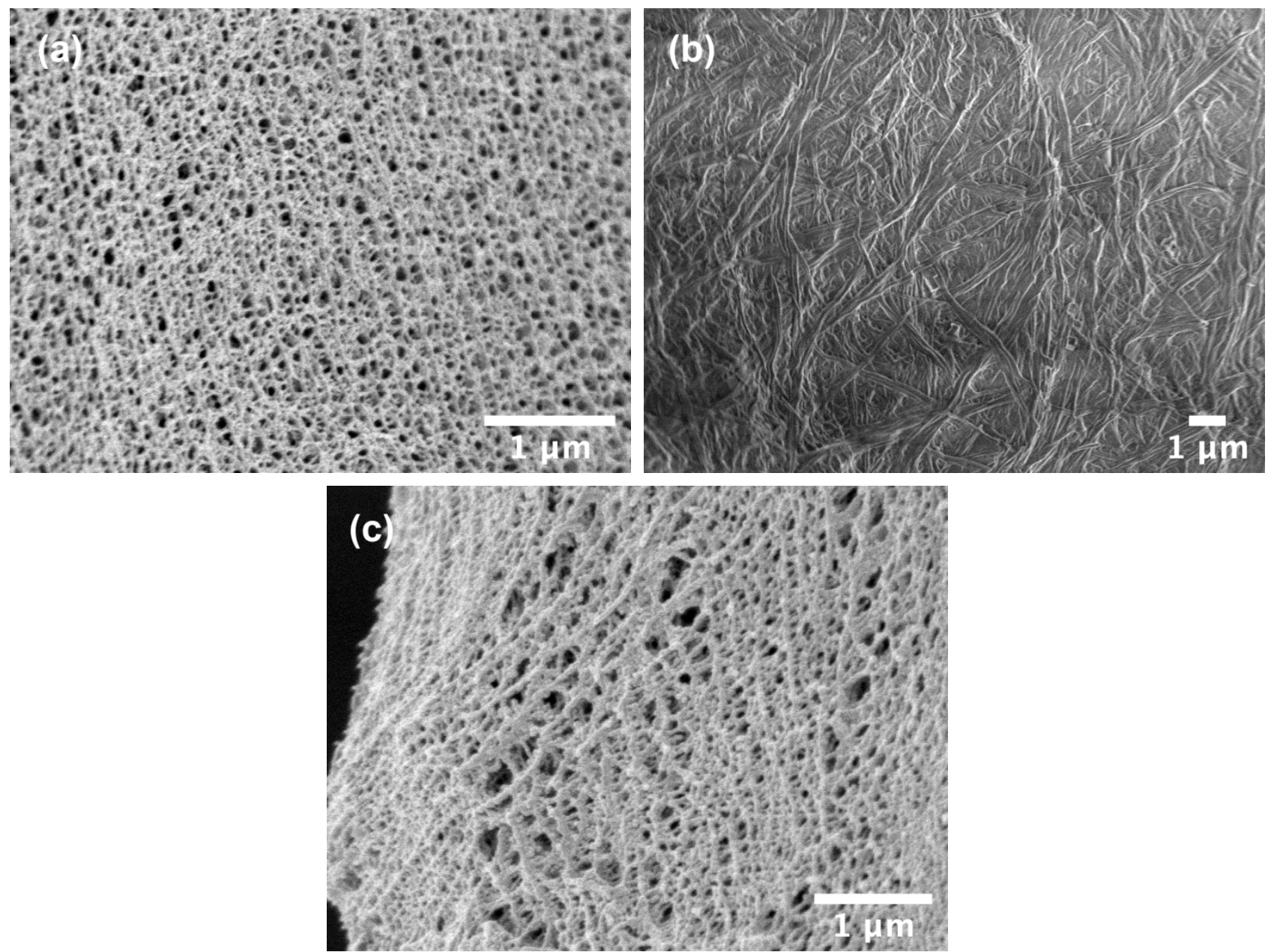

Figure 4: SEM micrographs typical of (a) PVC/bromobenzene gels, $\mathrm{C}_{\mathrm{PVC}}=4.8 \times 10^{-2} \mathrm{~g} / \mathrm{cm}^{3}$; (b) OPVOH16/bromobenzene, $\mathrm{C}_{\mathrm{OPVOH}}=4 \times 10^{-3} \mathrm{~g} / \mathrm{cm}^{3}$; (c) PVC/OPVOH16/bromobenzene gels, $\mathrm{C}_{\mathrm{PVC}}=$ $4.8 \times 10^{-2} \mathrm{~g} / \mathrm{cm}^{3}, \mathrm{C}_{\mathrm{OPVOH}}=4 \times 10^{-3} \mathrm{~g} / \mathrm{cm}^{3}$.

The formation and melting temperatures of the $\mathrm{OPVOH}$ gels at $\mathrm{C}_{\mathrm{OPV}}=0.4 \times 10^{-2} \mathrm{~g} / \mathrm{cm}^{3}$ as determined by DSC are $\mathrm{T}_{\text {gel }}=4 \pm 2^{\circ} \mathrm{C}$ with $\mathrm{T}_{\mathrm{m}}=40 \pm 4^{\circ} \mathrm{C}$ for OPVOH16/BB, and $\mathrm{T}_{\text {gel }}=-10 \pm 2^{\circ} \mathrm{C}$ with $\mathrm{T}_{\mathrm{m}}=40 \pm 4{ }^{\circ} \mathrm{C}$ for OPVOH12/BB. The low values of the formation and melting enthalpies suggest that not all the 
OPVOH molecules participate in the formation of the gel scaffold, a subsequent fraction still remaining in the SOL state. Indeed, the enthalpies values for the pure OPVOHs are $\Delta \mathrm{H}_{\mathrm{OPVOH} 12}=78$ $\mathrm{J} / \mathrm{g}$ and $\Delta \mathrm{H}_{\mathrm{OPVOH} 16}=101 \mathrm{~J} / \mathrm{g}$, which should give $\Delta \mathrm{H}=0.31$ to $0.4 \mathrm{~J} / \mathrm{g}$

Determination of the gel formation temperatures of the binary systems therefore show that the PVC network forms well before the OPVOHs molecules can organize. As a result, in the ternary systems, the OPVOHs fibrils are forced to grow in a medium filled with subsequent “obstacles". In addition, the available space for a fibril to grow, namely determined by the PVC gel mesh size, is about the same order of magnitude as their cross-sections.

In the case of the ternary system PVC/OPVOH/BB, a gel is also produced where the OPVOH molecules are homogeneously dispersed (figure 2 left). That OPVOH molecules have undergone some degree of organization is confirmed by the occurrence of melting endotherms and formation exotherms (see SI Figure S3, DSC traces). The associated temperatures are not significantly altered in spite of the presence of the PVC network (figure 3 and see SI Table S1). There is no clear tendency as to whether the corresponding enthalpies depend upon the PVC content.

The typical morphology of these ternary gels is basically similar to that of the binary system although the network appears somewhat looser (figure 4c). The organogel fibrils cannot be distinguished. That the OPVOH fibrils grow within a network of rather small mesh size may possibly alter the original organogel morphology. 

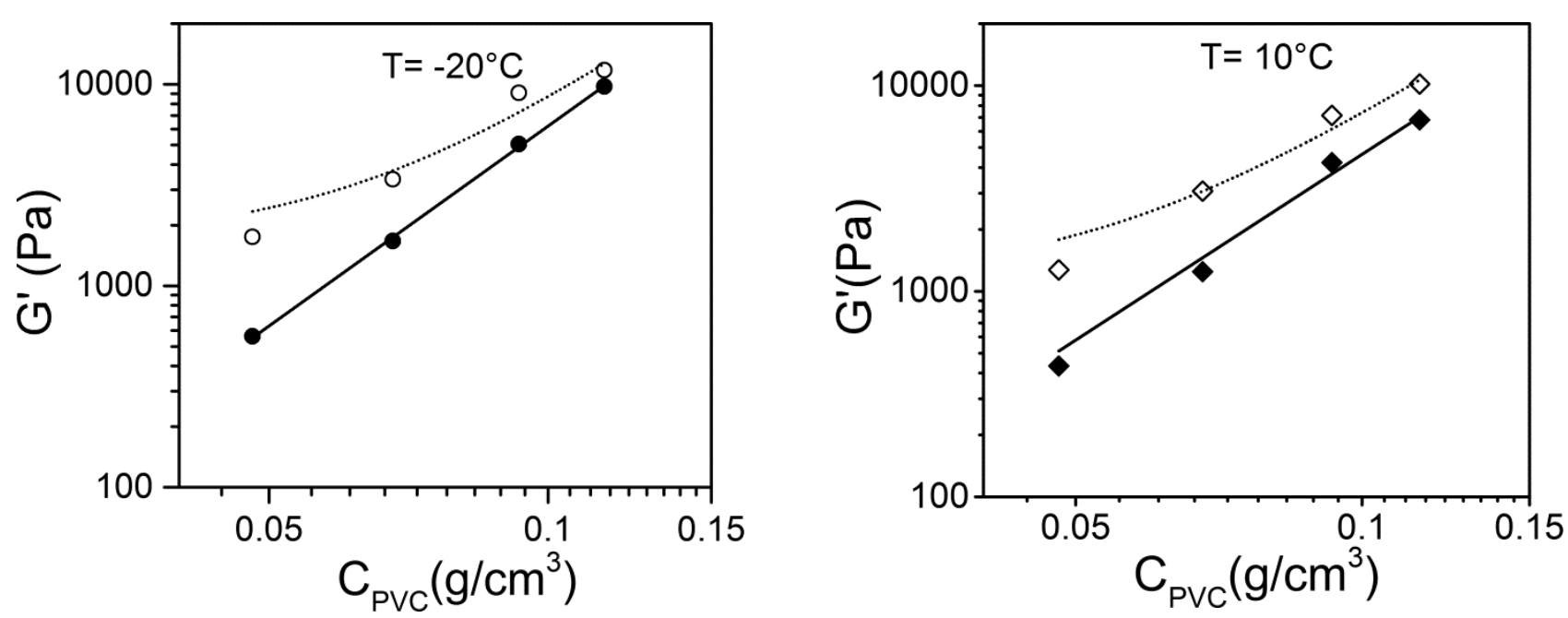

Figure 5: Variation of the elastic modulus $\mathrm{G}^{\prime}$ as determined at frequency $=1 \mathrm{~Hz}$ and at $\mathrm{T}=-20^{\circ} \mathrm{C}$ (left) and $\mathrm{T}=10^{\circ} \mathrm{C}$ (right) for PVC/bromobenzene gels $(\bullet, \bullet)$ and PVC/OPVOH16/bromobenzene gels $(\bigcirc, \diamond)$.

Rheological experiments were further performed on the ternary system OPVOH16/PVC/bromobenzene by measuring the shear modulus $G^{\prime}$ as a function of PVC concentration at constant OPVOH16 content $\left(\mathrm{C}_{\mathrm{OPV}}=0.4 \times 10^{-2} \mathrm{~g} / \mathrm{cm}^{3}\right)$. The hot PVC solutions were quenched between the plates of the rheometer at three different quenching temperatures, $-20^{\circ} \mathrm{C}$, $10^{\circ} \mathrm{C}$ and $20^{\circ} \mathrm{C}$, and subsequently studied at these temperatures. As $\mathrm{G}^{\prime}$ is a constant throughout the explored frequency range once gelation has set in, its value was systematically determined at a frequency of $1 \mathrm{~Hz}$ (SI figure S4, G' and G3 vs frequency) and in figure S5 and table S2, G' vs PVC concentration). The typical behavior observed for these ternary systems is reported in figure 5 together with the behavior of the corresponding binary gels.

The intermingling of the OPVOH organogel with the PVC physical network results in a conspicuous increase of the elastic modulus at low PVC concentrations, which gradually vanishes at higher PVC concentrations. Clearly, a rather strong reinforcement of the PVC gel mechanical properties occurs with a relatively low amount of OPVOH. 
The model by Takayanagi et al. ${ }^{27}$ and by Zhang and Rochas ${ }^{28}$ derived for mixed gels of compatible biopolymers may be considered in the present case. In this model the shear modulus of the hybrid gel is simply the sum of the moduli of each component:

$$
G_{h y b}^{\prime}=G_{O P V}^{\prime}+G_{P V C}^{\prime}(C)
$$

As we have determined experimentally $G_{P V C}^{\prime}(C)$ at $-20^{\circ} \mathrm{C}$, namely:

$$
G_{P V C}^{\prime}(C)=9.26 \times 10^{6} C_{P V C}^{3.17}(\mathrm{~Pa})
$$

and at $\mathrm{T}=+10^{\circ} \mathrm{C}$ :

$$
G_{P V C}^{\prime}(C)=4.62 \times 10^{6} C_{P V C}^{3.0}(\mathrm{~Pa})
$$

The fit yields $G_{O P V}^{\prime}=2217 \pm 660 \mathrm{~Pa}$ at $\mathrm{T}=-20^{\circ} \mathrm{C}$ and $G_{O P V}^{\prime}=1090 \pm 700 \mathrm{~Pa}$ at $\mathrm{T}=+10^{\circ} \mathrm{C}$. Since increasing the temperature from $-20^{\circ} \mathrm{C}$ to $10^{\circ} \mathrm{C}$ entails partial melting of both networks the decrease seen for $G_{O P V}^{\prime}$ is expected (see SI figure S5, and table S2).

The shear modulus of the $\mathrm{OPVOH}$ organogel has been measured at a concentration of $\mathrm{C}_{\mathrm{OPVOH}}=$ $4 \times 10^{-3} \mathrm{~g} / \mathrm{cm}^{3}$ at the same temperatures in order to test the validity of the above approach. The same experimental protocol, namely heating at the same temperature and cooling at the same rate, was applied to all the samples.

For $\mathrm{T}=-20^{\circ} \mathrm{C}$ and $\mathrm{T}=10^{\circ} \mathrm{C}$ it is found $G_{O P V}^{\prime}=2239 \mathrm{~Pa}$ and $G_{O P V}^{\prime}=981 \mathrm{~Pa}$, respectively (see SI table S2, and figure S6, G' vs PVC concentration). These values are in excellent agreement with those obtained from the theoretical fit which supports the assumption of combining linearly the modulus of each component.

The OPVOH organogel is made up with rigid objects, the fibrils, whose elasticity is of enthalpic nature ${ }^{17}$. The shear modulus of the network is then a combination of the intrinsic (bending) modulus of its constituting fibrils $e$ and of the number of physical cross-links per unit volume, the latter being expressed through the concentration of elastic material $\varphi$. For straight fibrils it is written ${ }^{29,8}$ :

$$
G^{\prime} \sim e \varphi^{2}
$$


Since the OPVOH concentration is rather low, this suggests that the OPVOH fibrils have a very high intrinsic modulus.

\section{The systems in benzyl alcohol}

The system $\boldsymbol{P} \boldsymbol{V} \boldsymbol{C} / \boldsymbol{B} \boldsymbol{A}$ separates into two phases when rapidly quenched to $0^{\circ} \mathrm{C}$ (see figure 2 ), where the polymer-rich phase is of the gel-like type. Turbidimetry experiments (SI figure S1) further show that a liquid-liquid phase separation is involved ${ }^{7}$ as ascertained by the observation of a miscibility gap delimited by a binodal curve in the temperature-concentration phase diagram (figure 3 right).

The location of the binodal curve at high temperature further confirms that benzyl alcohol is a very poor solvent to PVC. Morphological investigations by scanning electron microscopy (SEM) reveal an array of spherical objects of the "meat-ball" type of about $1 \mu \mathrm{m}$ diameter, that are more or less connected so as to form a network in the early stage of the phase separation (figures 6a). Yet, this system is not strictly speaking a gel but rather a transient network that eventually collapses in the course of time ${ }^{17}$, resulting in the formation of two macroscopically-separated phases (figure 2). As the PVC balls are frozen in by a low degree of crystallinity ${ }^{7}$ they do not fuse into a continuous, structureless polymer-rich phase as would do an amorphous polymer.

OPVOHs molecules form gels in BA of typical fibrillar morphology (figure 6b). The mesh size rather lies in the micron range in the concentration domain considered in this study $\left(\mathrm{C}_{\mathrm{OPV}}=0.4 \times 10^{-2}\right.$ $\mathrm{g} / \mathrm{cm}^{3}$ ), while the fibrils possess cross-sections in the range 100-500 $\mathrm{nm}$ that are significantly larger than those of $\mathrm{OPVOH} / \mathrm{BB}$ gels. The formation and melting temperatures of the gels at $\mathrm{C}_{\mathrm{OPV}}=$ $0.4 \times 10^{-2} \mathrm{~g} / \mathrm{cm}^{3}$ as determined by DSC are $\mathrm{T}_{\mathrm{gel}}=45 \pm 3^{\circ} \mathrm{C}$ and $\mathrm{T}_{\mathrm{m}}=74 \pm 5^{\circ} \mathrm{C}$. 

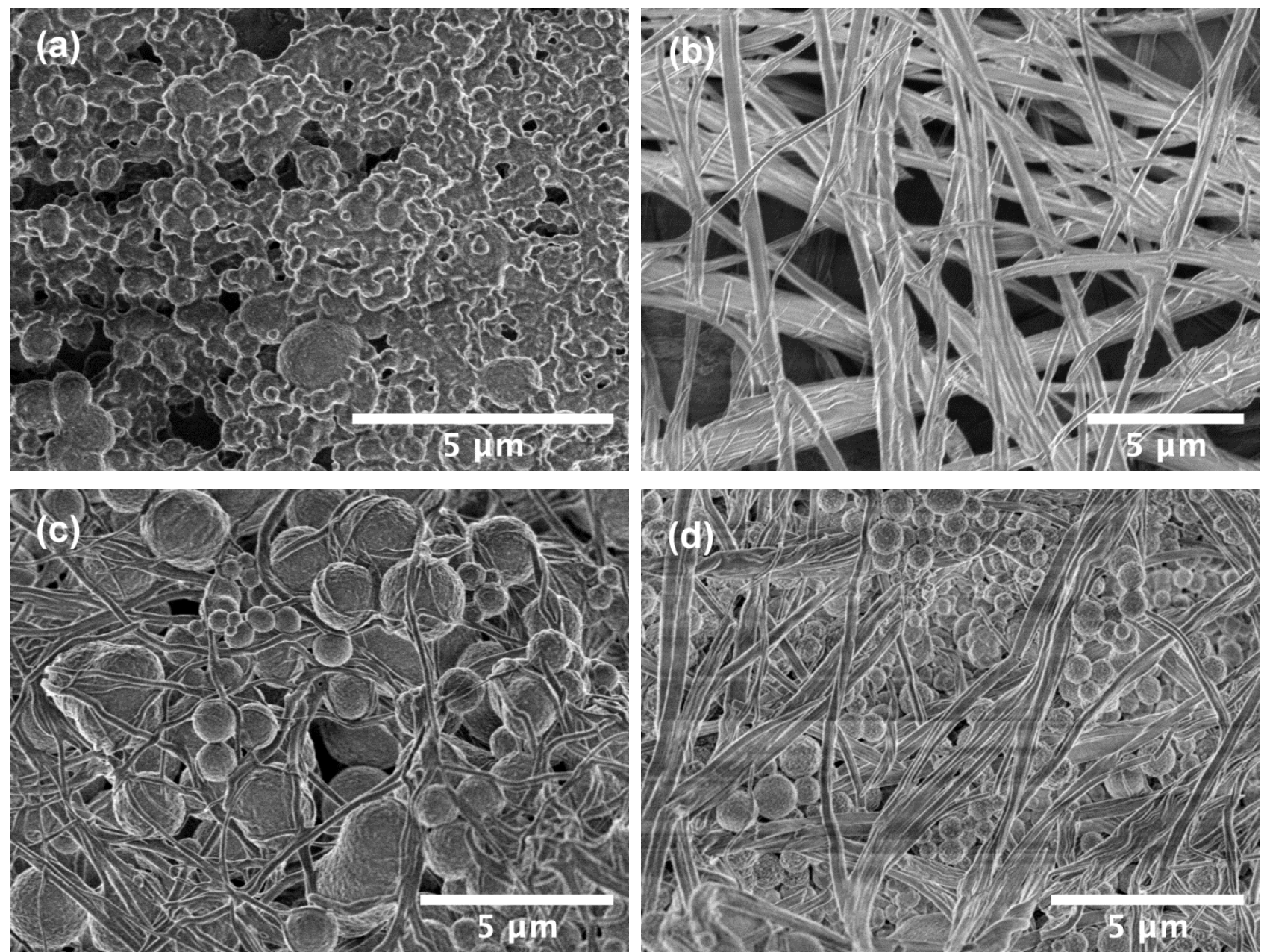

Figure 6: SEM micrographs typical of: (a) PVC/benzyl alcohol, $C_{P V C}=4.8 \times 10^{-2} \mathrm{~g} / \mathrm{cm}^{3}$; (b) OPVOH/benzyl alcohol, $C_{O P V O H}=4 \times 10^{-3} \mathrm{~g} / \mathrm{cm}^{3}$; (c) PVC/OPVOH12/benzyl alcohol, $C_{P V C}=4.8 \times 10^{-}$ ${ }^{2} \mathrm{~g} / \mathrm{cm}^{3}, C_{O P V O H}=4 \times 10^{-3} \mathrm{~g} / \mathrm{cm}^{3}$; (d) PVC/OPVOH16/benzyl alcohol, $C_{P V C}=4.8 \times 10^{-2} \mathrm{~g} / \mathrm{cm}^{3}, C_{O P V O H}=$ $4 \times 10^{-3} \mathrm{~g} / \mathrm{cm}^{3}$.

The ternary system $\boldsymbol{P V C / O P V O H / B A}$ does not display any noticeable solvent release unlike the binary system PVC/BA figure 2. Also, no macroscopic phase separation between the PVC and OPVOH components occurs in the course of time as the yellow colour remains homogeneous throughout.

The occurrence of the OPVOHs gels formation and melting within the ternary system has been determined by DSC (see SI Figure S3). Data reported in the temperature-concentration phase diagram of figure 3 right reveal that the gel formation temperatures of both OPVOHs are virtually unaltered by the presence of the PVC structures, nor are the melting temperatures (detailed values 
are given in SI table S1). Only the corresponding enthalpies seem to decrease with the increasing amount of PVC. This may imply that a lesser amount of OPVOH molecules form the organogel scaffold (the gel phase) while a significant part remains dissolved (the sol phase). This would further suggest that all happens as if the presence of PVC improved the solvent quality towards OPVOH. Yet, the low values measured for the enthalpies do not allow one to draw unquestionable conclusions on this point.

SEM observations unveil that the PVC "meat-balls" are actually imprisoned in the OPVOH gel (figures $6 \mathrm{c}$ and $6 \mathrm{~d}$ ). This outcome accounts for the absence of solvent release for the aged ternary systems. Evidently, the presence of existing PVC structures has virtually no influence on the thermodynamic of the gelation process of OPVOH molecules, nor has it on the final organogel morphology. A difference can, however, be observed between OPVOH12 and OPVOH16 gels. OPVOH12 fibrils interact extensively with the PVC balls by wrapping them unlike OPVOH16 fibrils. The reason is presently not clear but most probably related to the length of the paraffinic moieties.

\section{CONCLUDING REMARKS}

In this paper we show that a hybrid material made up with PVC and an organogelator can be straightforwardly prepared by a simple process which consists in cooling homogeneous, ternary solutions. This achievement is made possible thanks to two essential properties: i) PVC and the organogelator are compatible in solutions at elevated temperature, and ii) the organogel formation is not impeded by the presence of the existing PVC structures. In the case of PVC/bromobenzene gels it is observed that the gel mechanical properties are dramatically improved by incorporation of a low amount of organogelator. In the case of PVC/benzyl alcohol, the pervading organogel prevents the collapse of the transient network, which to some extent is also an improvement of the mechanical properties. 
The present outcomes further strengthen recent studies that have established the principle of functionalizing polymers with organogelators ${ }^{19-24}$. Imparting a functional property to PVC without any additional chemistry is therefore feasible. Here, OPVOH possesses opto-electronic properties, which results in a change of colour (sup. Info. S7, change of colour at the SOL-GEL transition) at the melting of the organogel fibrils while the PVC network remains unaltered ${ }^{15,19}$. After appropriate drying the porous material could be used as a sensor for detecting in air or in water undesired molecules that are capable of dissolving or even slightly altering the OPVOH scaffold. This is but one example of possible applications.

Corresponding Author jean-michel.guenet@ics-cnrs.unistra.fr; ORCID 0000-0002-3829-8303

Author Contributions This article is part of Z.Z. thesis. M.S. and A.C. performed the SEM investigations, A.A and V.K.P. provided the OPV molecules, D. C. carried out the rheological part and the turbidimetry measurements, S.E. and J.M.G. supervised the work.

Notes The authors declare no competing financial interest

Acknowledgments: The authors are indebted to C. Saettel for the DSC investigations. 


\section{REFERENCES}

1) See for instance Gnanou, Y.; Fontanille, M. Organic and Physical Chemistry of Polymers, 2008 John Wiley \& Sons, , N.Y.

2) Stein, R.S.; Tobolsky, A.V. An investigation of the relationship between polymer structure and mechanical properties: Part II: An Experimental Study of the Stress and Birefringence Properties Text. Res. J. 194918302

3) Alfrey, T.; Wiederhorn, N.; Stein, R.S.; Tobolsky, A.V. Some studies of plasticized polyvinylchloride J. Colloid. Sci. 1949, 4, 211.

4) Walter, A.T. Elastic properties of polvinyl chloride gels J. Pol. Sci. 1954, 13, 207

5) Juijn, J.A.; Gisolf, A.; deJong, W.A. Crystallinity in atactic poly vinyl chloride Kolloid Z. Z. Polym. 1973, 251, 456

6) te Nijenhuis, K.T. and Dijkstra, H. Investigation of the aging process of a polyvinyl chloride gel by the measurement of its dynamic moduli Rheol. Acta 1975, 14, 71.

7) Mutin, P.H.; Guenet, J.M. Physical gels from PVC: ageing and solvent effect on thermal behavior, swelling and compression modulus. Macromolecules 1989, 22, 843.

8) Guenet, J.M. Polymer-solvent molecular compounds, 2008, Elsevier, London.

9) Abied, H.; Brûlet, A.; Guenet, J.M. Physical gels from PVC: molecular structure of pregels and gels by low angle neutron scattering Coll. Polym. Sci. 1990, 268, 403.

10) Lopez, D.; Dahmani, M.; Mijangos, C.; Brulet, A.; Guenet, J.M. Molecular structure by neutron scattering of thermoreversible gels from chemically-modified PVC Macromolecules 1994, 27, 7415 11) Daniel, C., Alfano, D., Venditto, V., Cardea, S., Reverchon, E., Larobina, D., Mensitieri, G., Guerra, G. Aerogels with a Microporous Crystalline Host Phase Adv. Mater. 2005, 17, 1515

12) Terech, P.; Weiss, R.G. Low molecular mass gelators of organic liquids and the properties of their gels Chem. Rev., 1997, 97, 3133-3159 
13) Terech, P.; Weiss, R.G., Editors Molecular Gels: Materials with Self-Assembled Fibrillar Networks, Springer Verlag, 2006

14) Liu, X.L.; Li, J.L. Soft Fibrillar Materials: Fabrication and Applications, Wiley-VCH, 2013

15) Ajayaghosh, A. and Praveen, V.K. $\pi$-Organogels of Self-Assembled p-Phenylenevinylenes: Soft Materials with Distinct Size, Shape, and Functions Acc. Chem. Res., 2007, 40, 644-656.

16) Weiss, R.G. The past, present and future of molecular gels. What is the status of the field, and where is it going? J. Am. Chem. Soc. 2014, 136, 7519-7530

17) Guenet, J.M. Organogels: thermodynamics, structure, solvent role and properties, 2016, N.Y., Springer International Publishing

18) Molecular Gels, Structure and Dynamics, Weiss, R.G. Ed., Monograph in Supramolecular Chemistry, 2018, Royal Society of Chemistry, London

19) Dasgupta, D.; Srinivasan, S.; Rochas, C.; Ajayaghosh, A.; Guenet, J.M. Hybrid thermoreversible gels from covalent polymers and organogels Langmuir 2009, 25, 8593;

20) Lopez, D.; Guenet, J.M. Encapsulation of filaments of a self-assembling bicopper complex in polymer nanowires. European Physical Journal B 1999 B12 405

21) A. Boulaoued, J.-L. Bantignies, R. Le Parc, C. Goze-Bac, P. Mesini, T.-T.-T. Nguyen, A. Al Ouahabi, P. Lutz, J.-M. Guenet Hybrid fibrillar xerogel with unusual magnetic properties Langmuir 2016, 32, 13193

22) Raj, G.; Boulaoued, A.; Lacava, J.; Biniek, L.; Mesini, P.J.;Brinkmann, M.; Faure-Vincent, J.; Guenet; J.M. Insulated Molecular Wires: Sheathing Semi-Conducting Polymers with Organic Nanotubes through Heterogeneous Nucleation Adv. Electron.Mater., 2017, 3, 1600370.

23) Bairi, P.; Chakraborty, P.; Shit, A.; Mondal, S.; Roy, B.; Nandi, A.K. A Co-assembled Gel of a Pyromellitic Dianhydride Derivative and Polyaniline with Optoelectronic and Photovoltaic Properties Langmuir 2014, 30, 7547. 
24) Guenet, J.M. Hybrid Physical Gels from Polymers and Self-Assembled Systems: A Novel Path for Making Functional Materials Gels 2018, 4, 35

25) George, S.J. and Ajayaghosh, A.Self-Assembled Nanotapes of Oligo(p-phenylene vinylene)s: Sol-Gel-Controlled Optical Properties in Fluorescent $\pi$-Electronic Gels Chem. -Eur. J., 2005, 11, 3217.

26) Yang, Y.C. and Geil, P.H. Morphology and properties of PVC/solvent gels J. Macromol. Sci. 1983, $B(22), 463$

27) Takayanagi, M.; Harima, H.; Iwata, Y Viscoelastic behavior of polymer blends and its comparison with model experiments Mem. Fac. Eng. Kyushu Univ. 1963, 23, 1

28) Zhang, J.; Rochas, C. Interactions between agarose and $\kappa$-carrageenans in aqueous solutions Carbohydr. Polym. 1990, 13, 21

29) Jones, J. L.; Marques, C. M. Rigid polymer network models J. Phys. (les Ulis) 1990, 51, 1113 

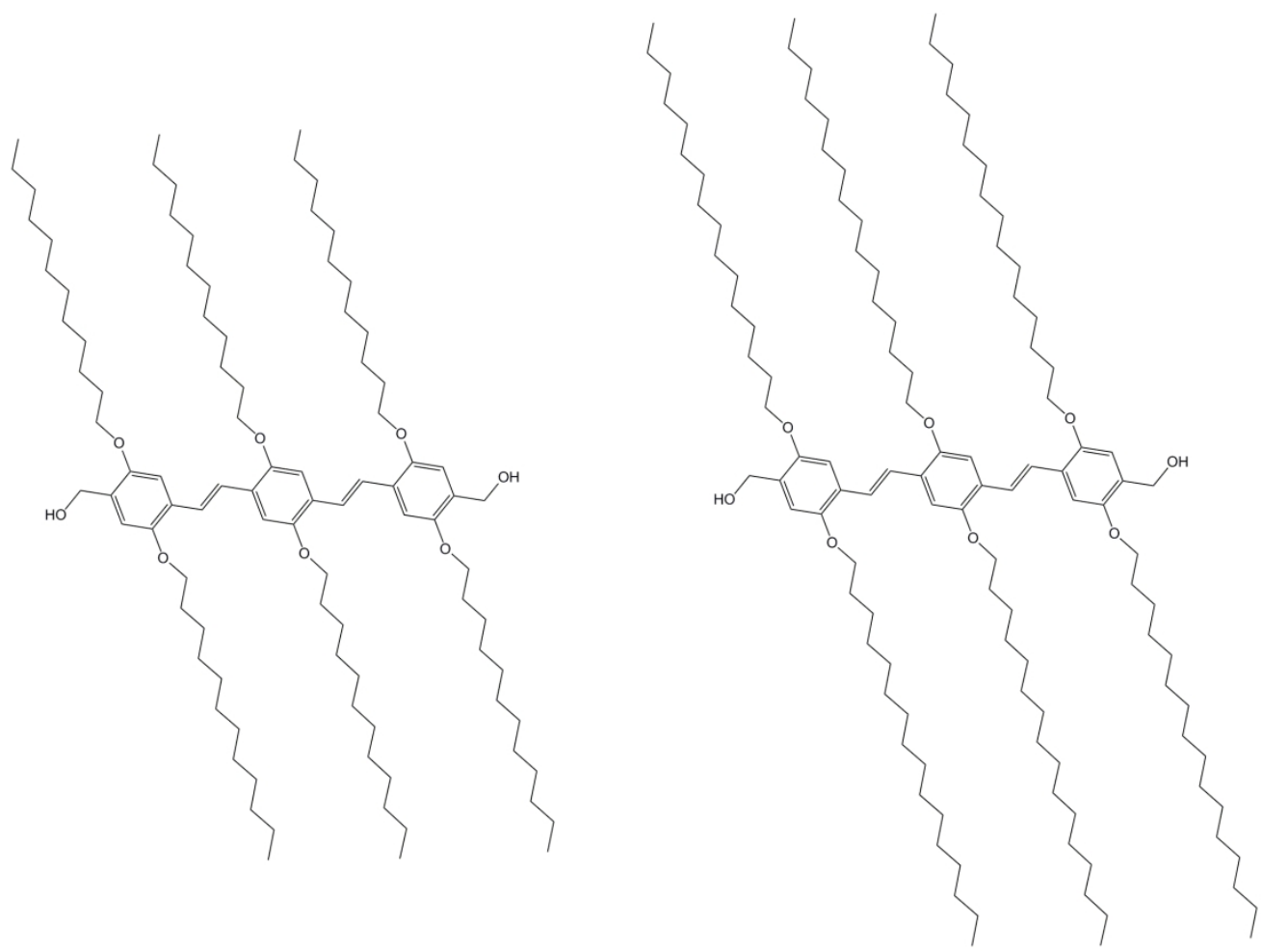

$190 \times 142 \mathrm{~mm}(300 \times 300$ DPI $)$ 


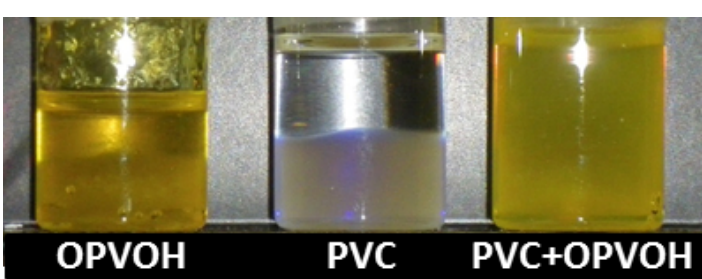

Benzyl alcohol

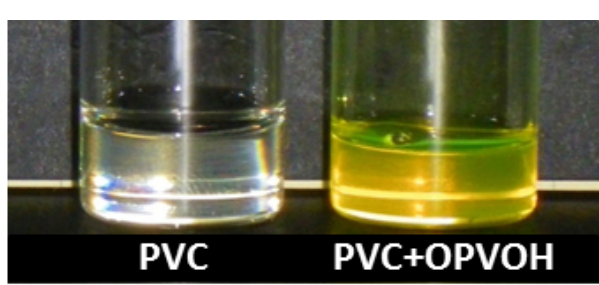

Bromobenzene

$195 \times 50 \mathrm{~mm}(96 \times 96 \mathrm{DPI})$ 


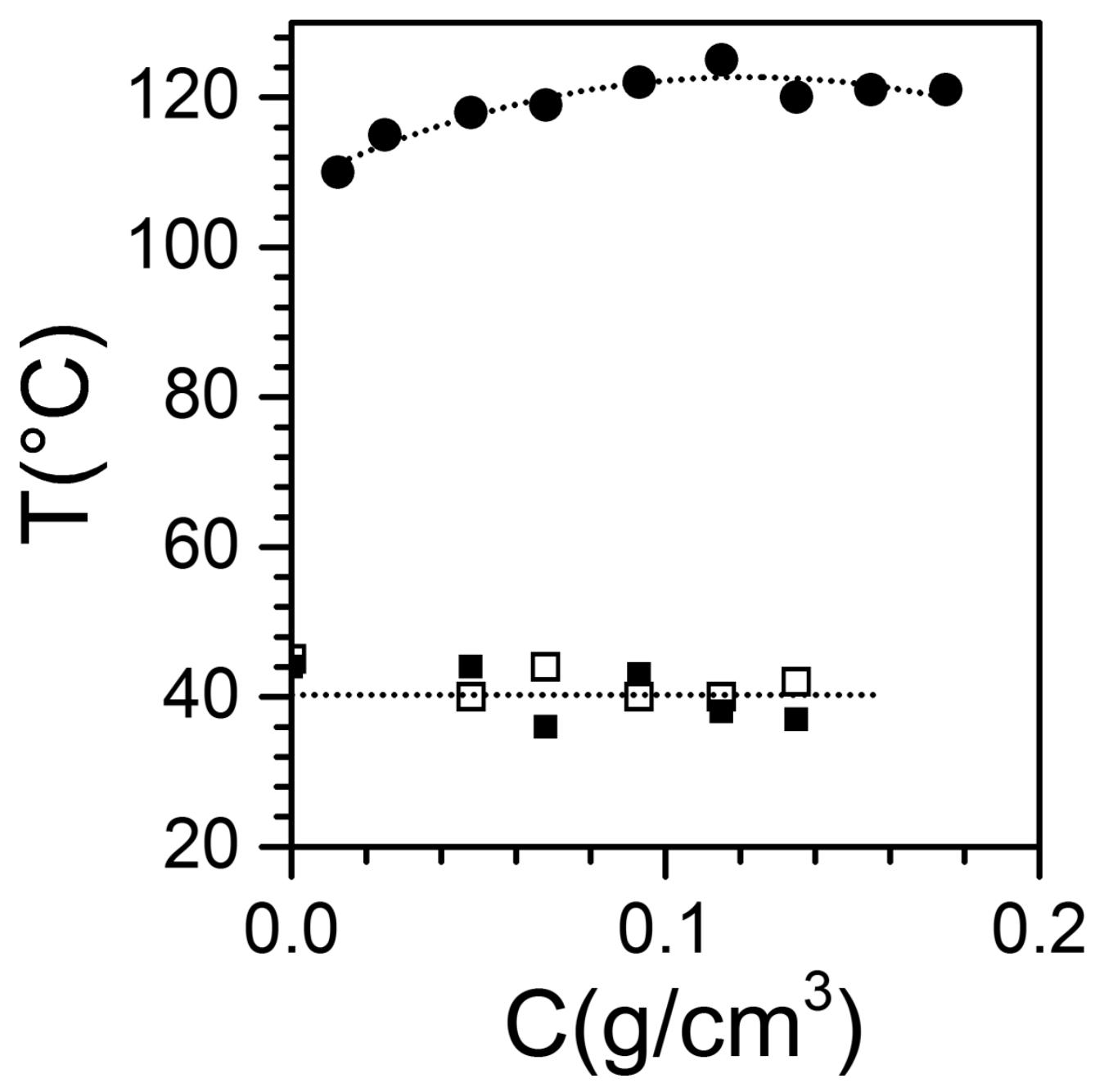

$193 \times 191 \mathrm{~mm}(300 \times 300$ DPI $)$ 


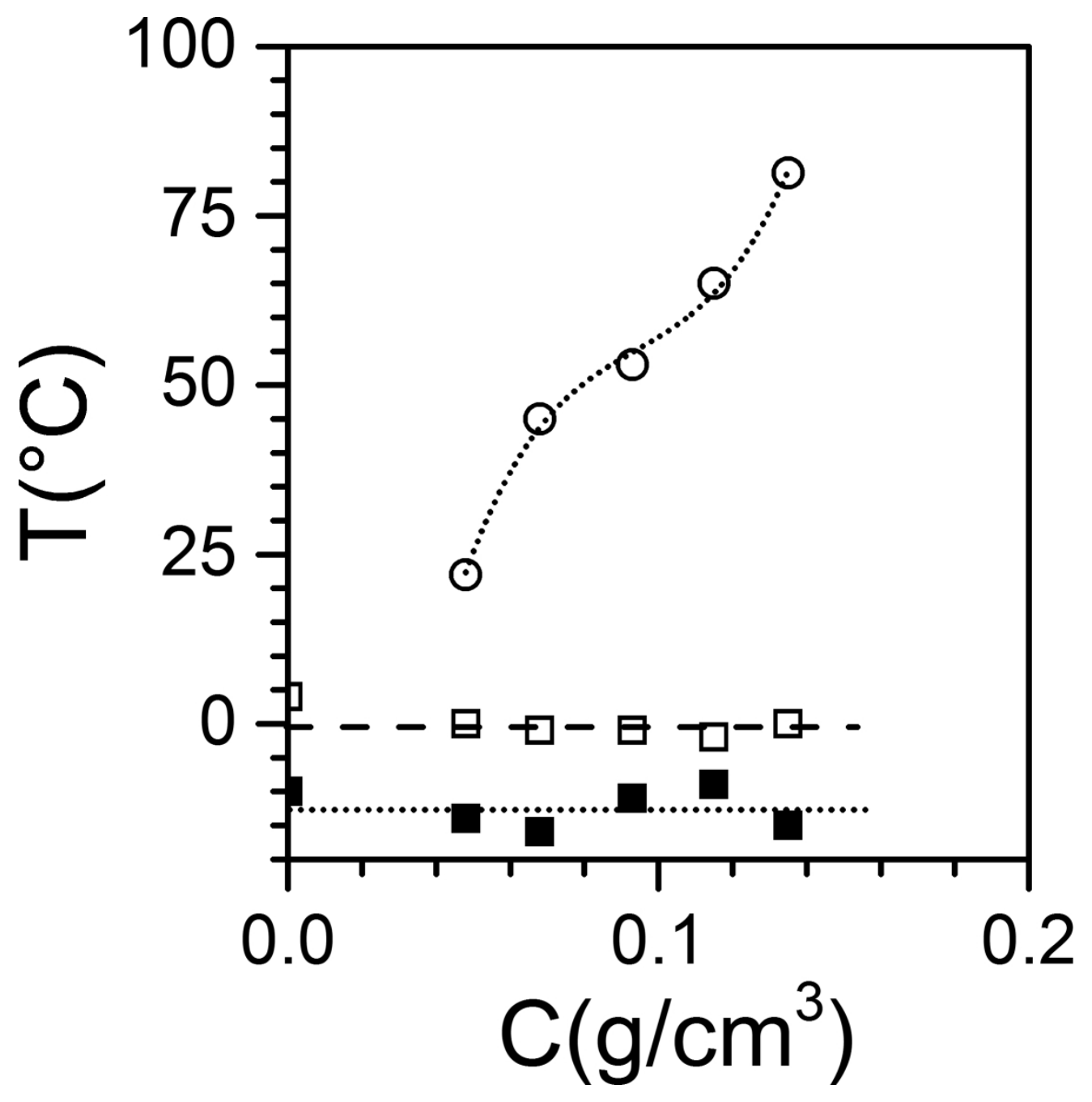

$193 \times 196 \mathrm{~mm}(300 \times 300 \mathrm{DPI})$ 


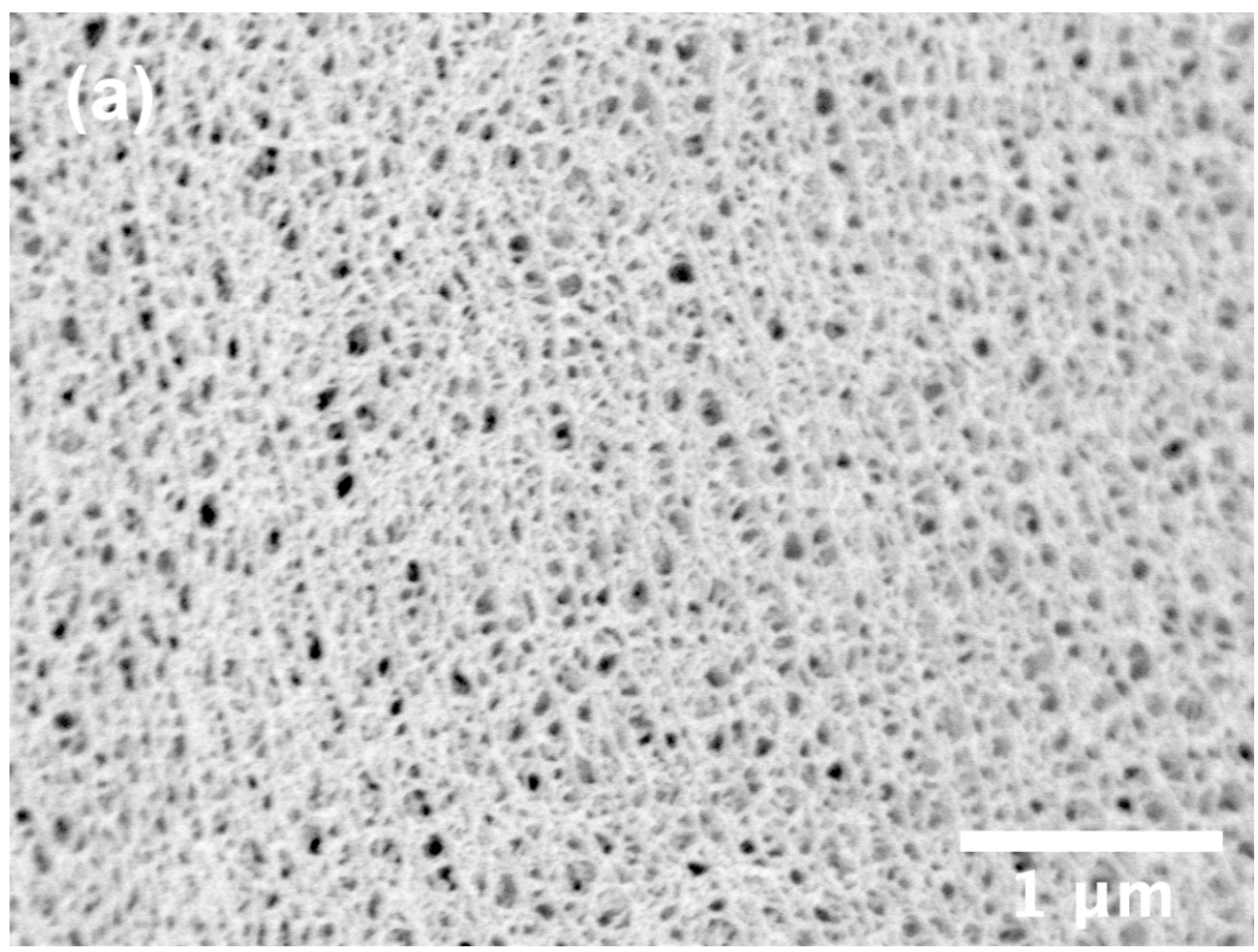




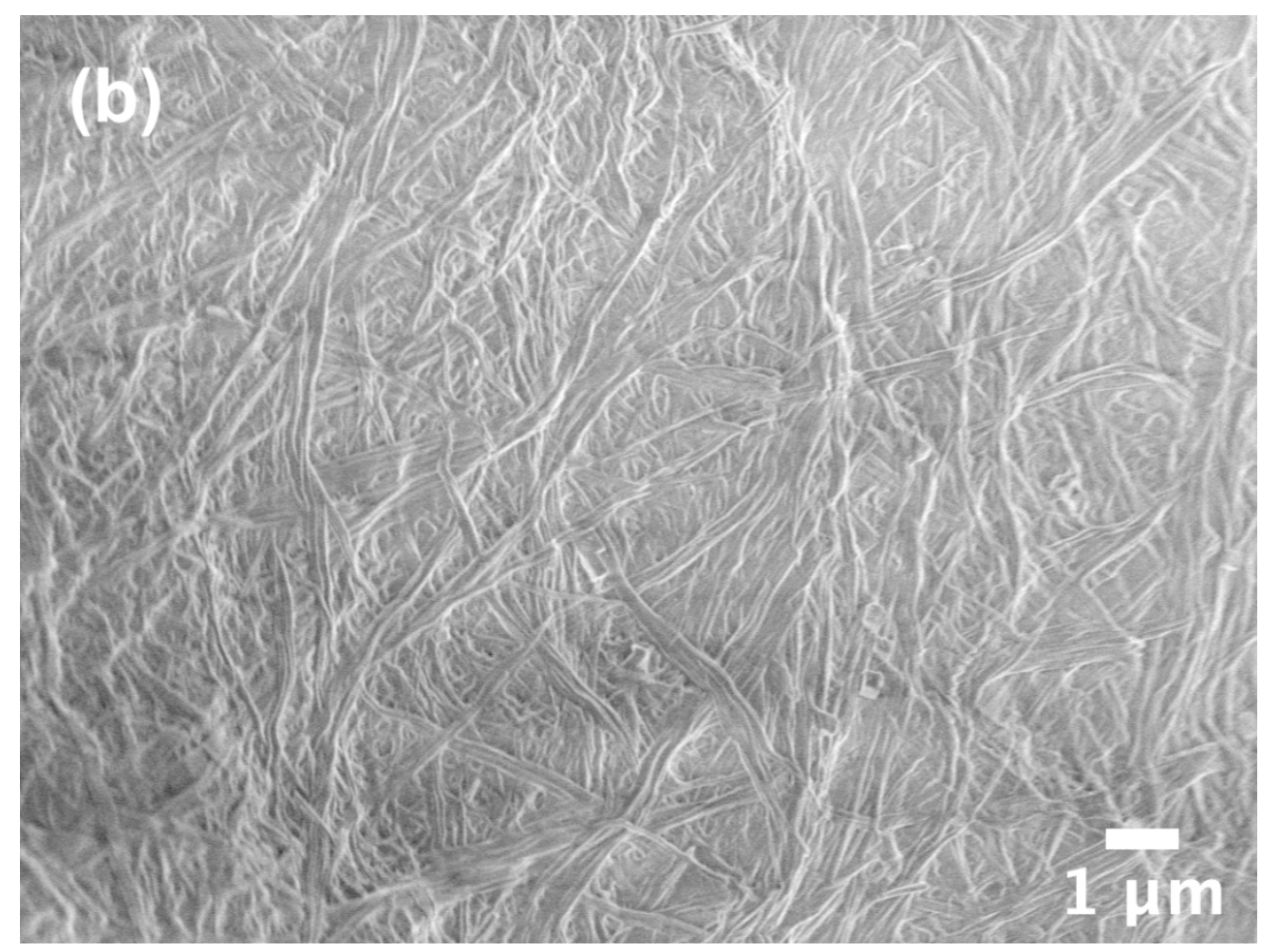




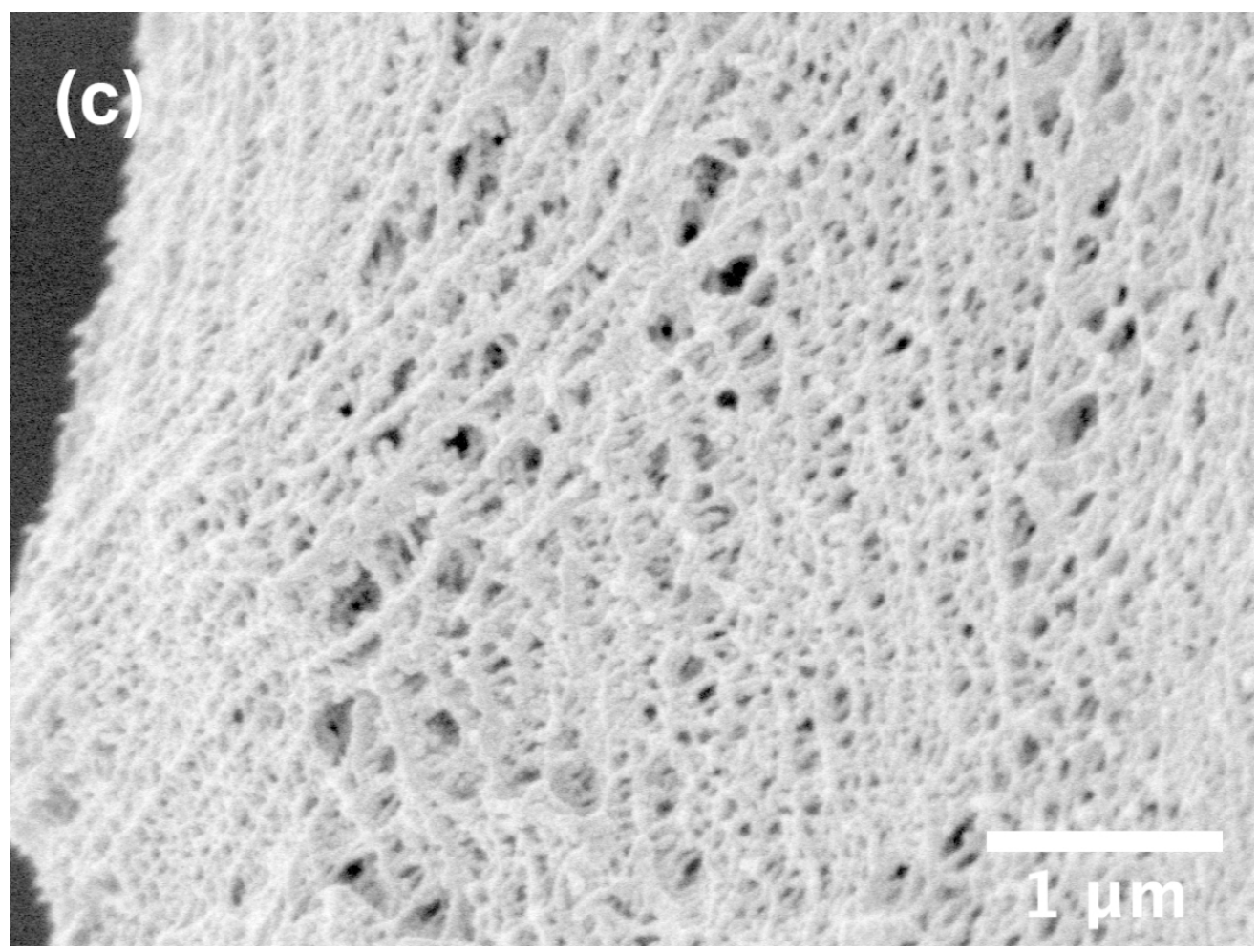




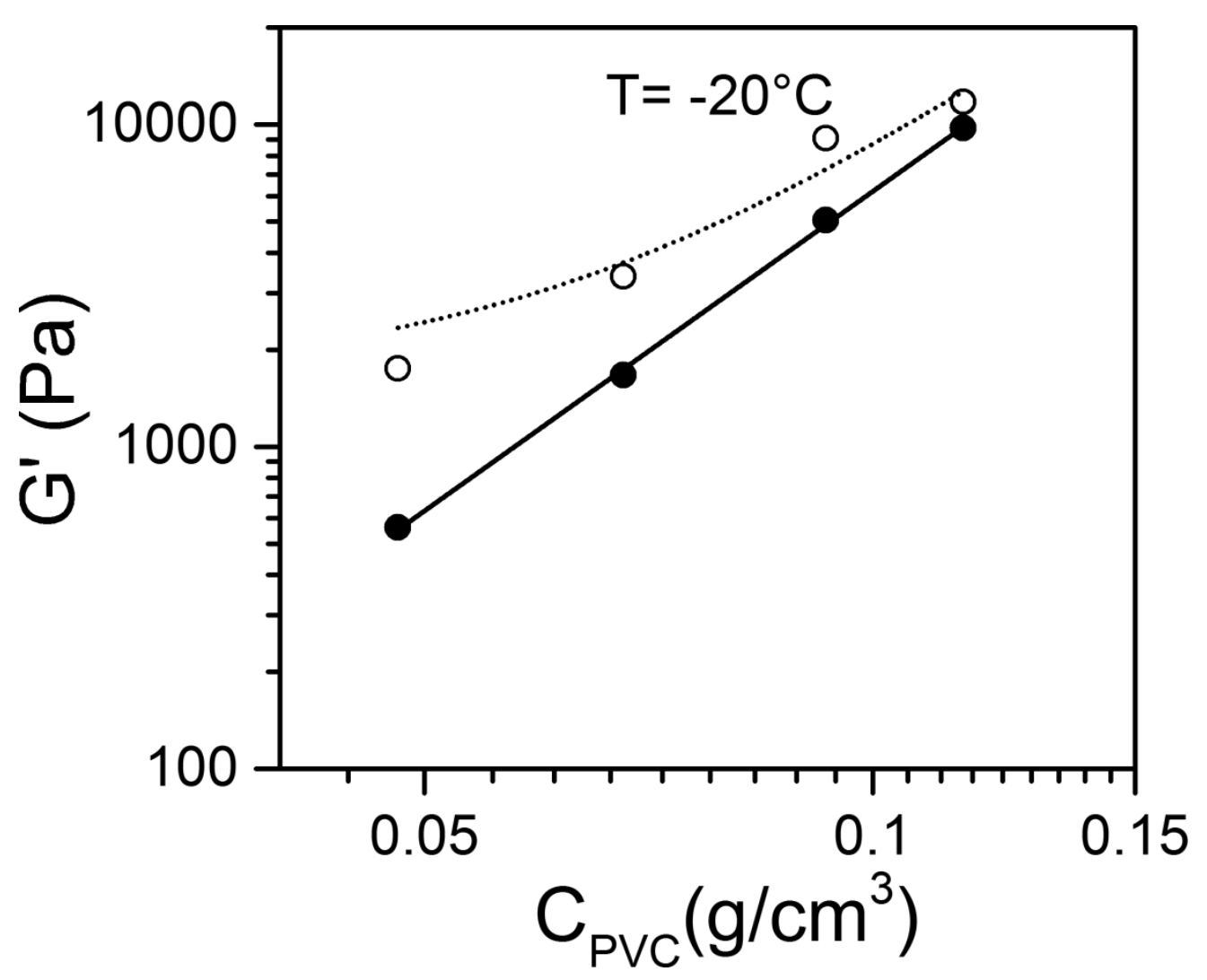

$223 \times 180 \mathrm{~mm}(300 \times 300 \mathrm{DPI})$ 


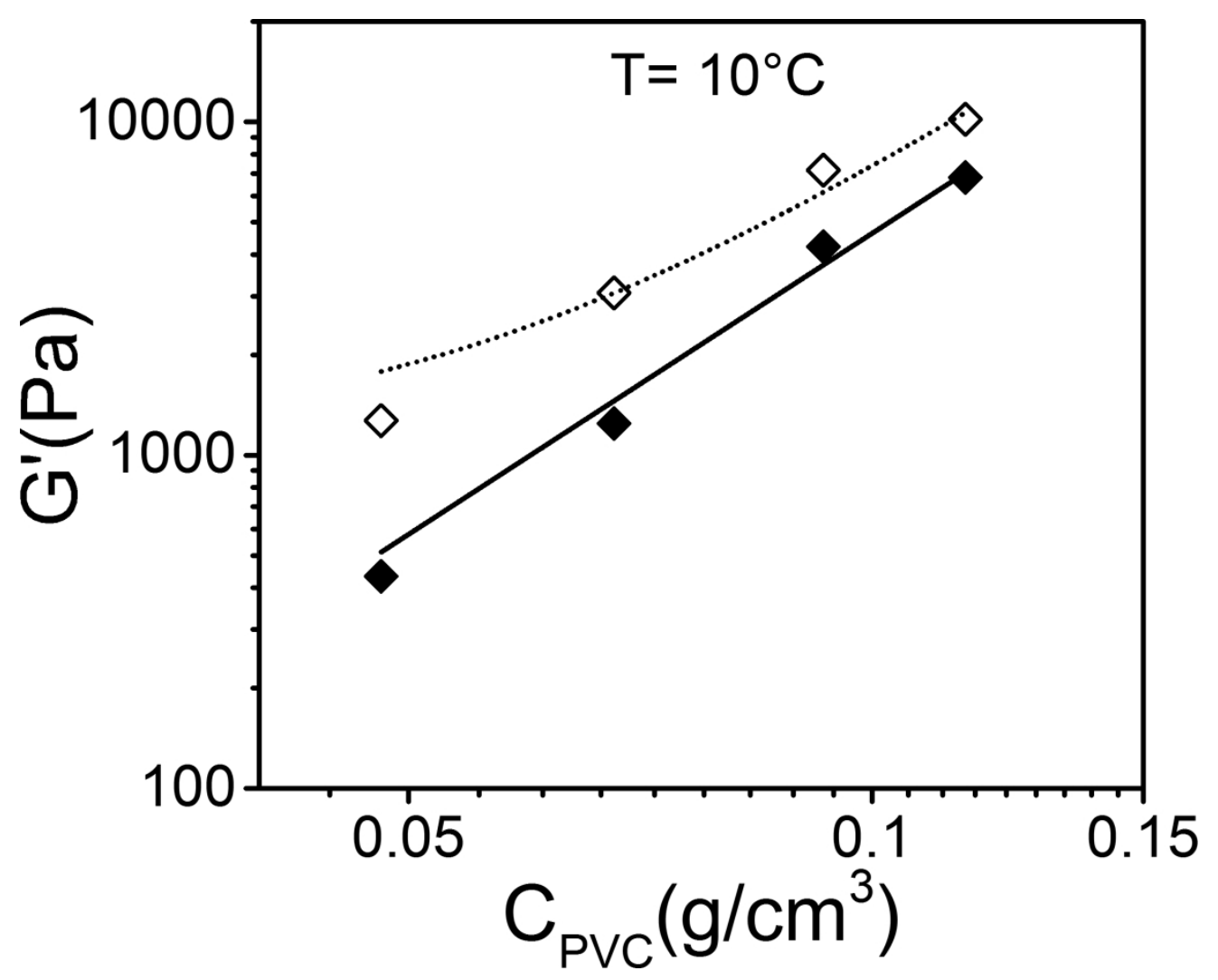

$217 \times 175 \mathrm{~mm}(300 \times 300 \mathrm{DPI})$ 


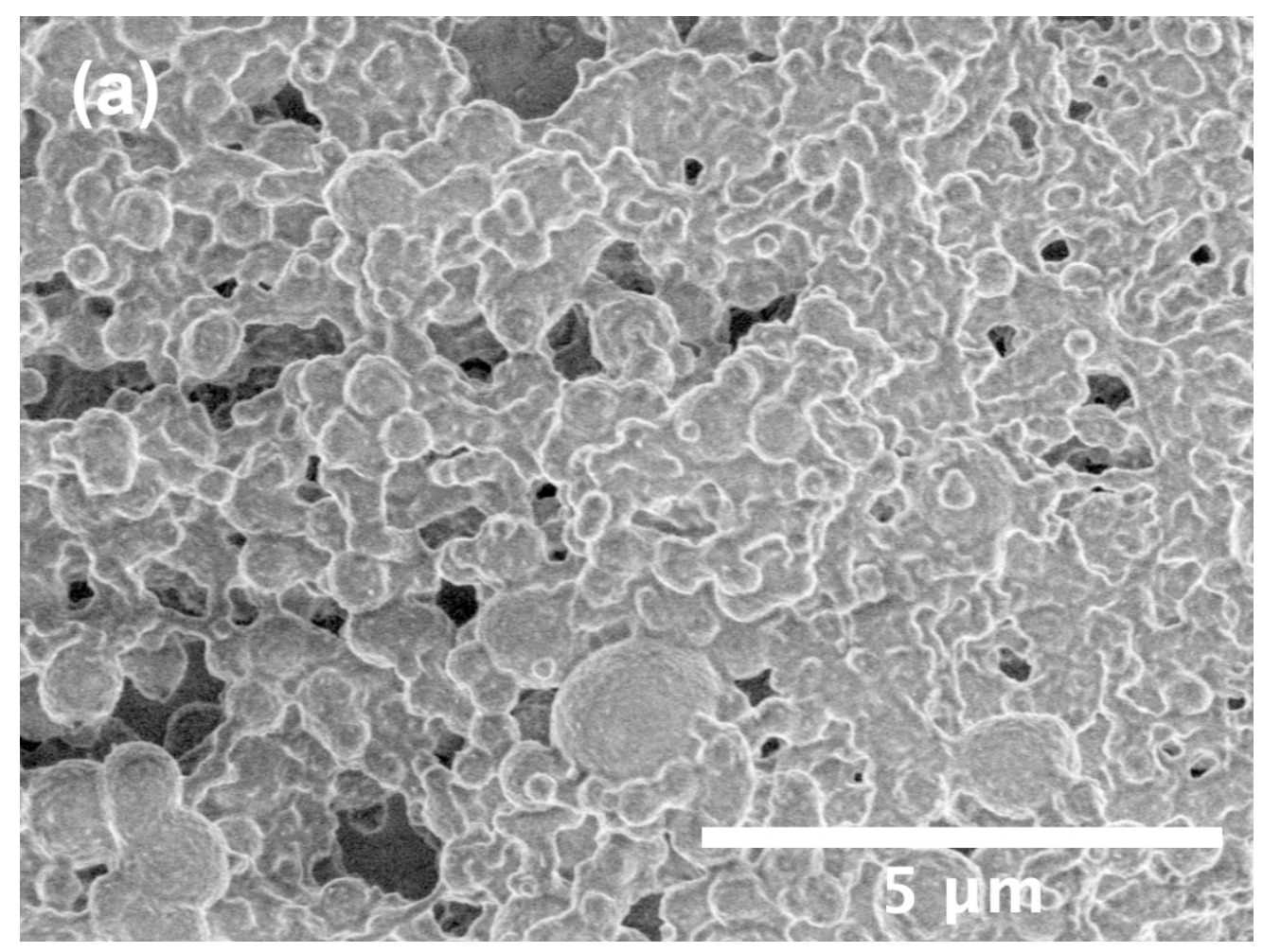




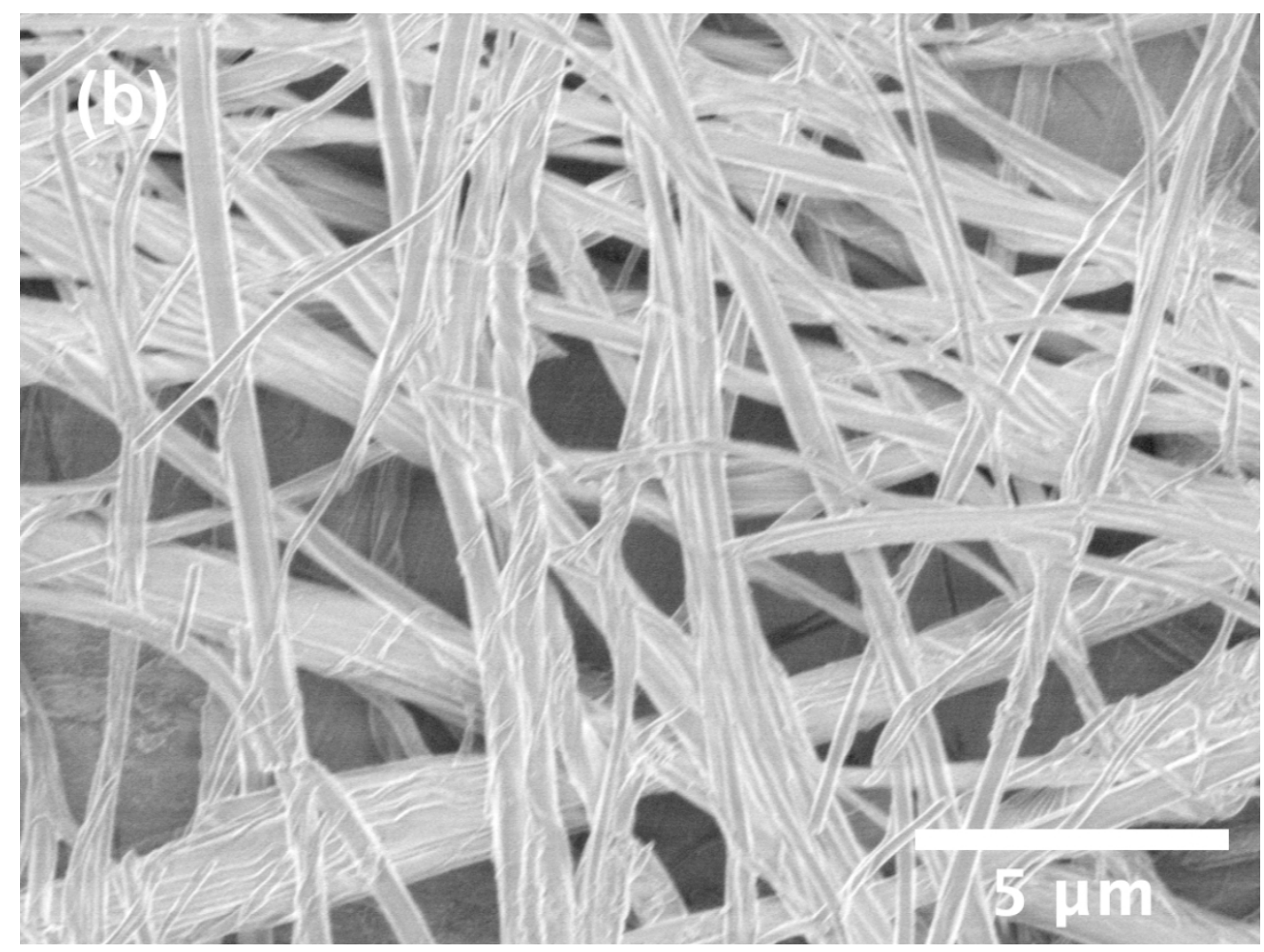




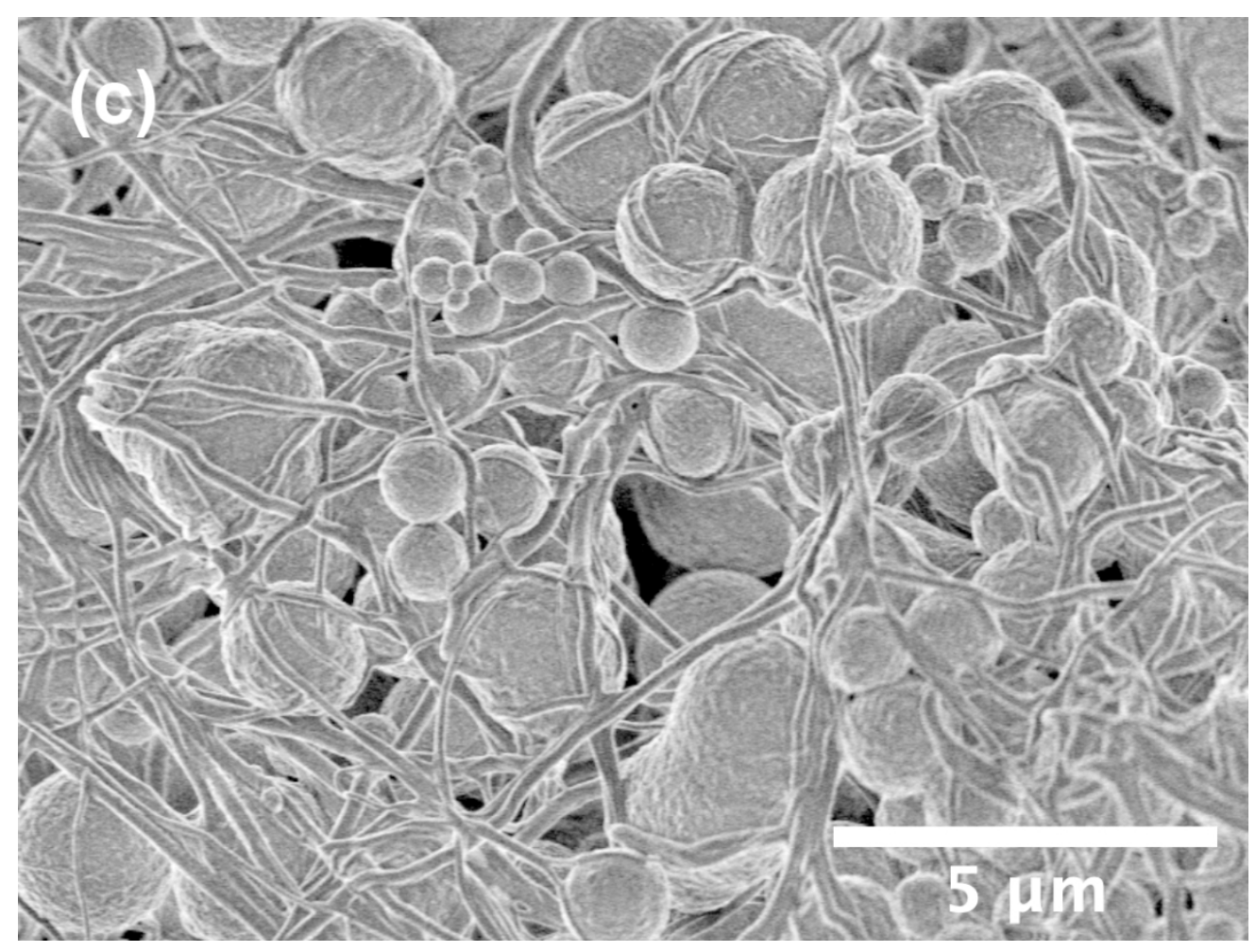




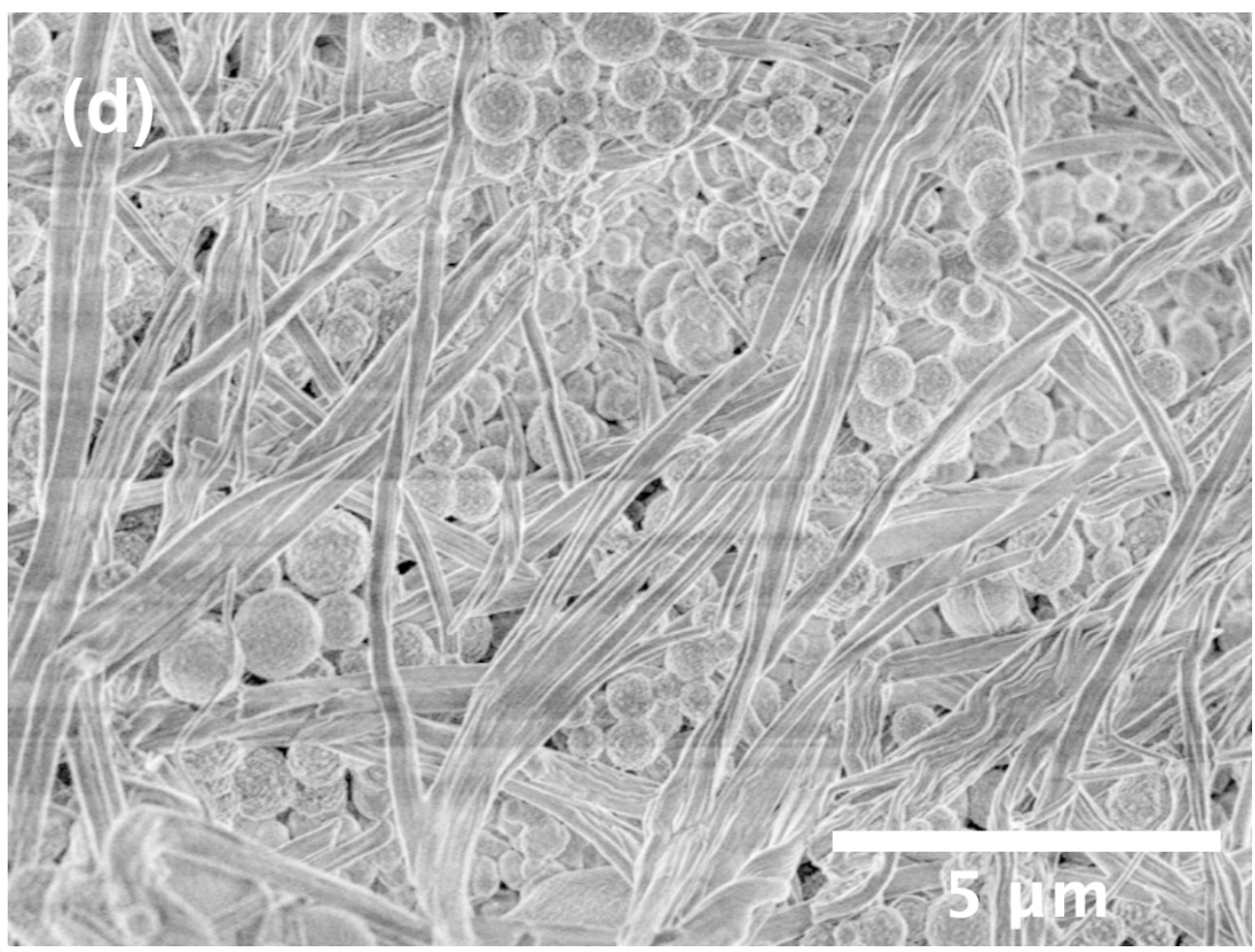

